Archived version from NCDOCKS Institutional Repository http://libres.uncg.edu/ir/asu/

Williams, Marian R., Demuth, S., and Holcomb, Jefferson E. (2007). Understanding the influence of victim gender in death penalty cases: The importance of victim race, sex-related victimization, and jurydecision-making. Criminology, 45, 865-892. DOI: 10.1111/j.1745-9125.2007.00095.x

(ISSN: 0011-1384) Wiley-Blackwell. The definitive version is available at www3.interscience.wiley.com

\title{
Understanding The Influence Of Victim Gender In Death Penalty Cases: The Importance Of Victim Race, Sex-Related Victimization, and Jury Decision Making*
}

\author{
MARIAN R. WILLIAMS \\ STEPHEN DEMUTH \\ JEFFERSON E. HOLCOMB
}

KEYWORDS: death penalty, race, gender, victims

\begin{abstract}
Using data from the Baldus, Woodworth, and Pulaski (1990) study of Georgia's death penalty system, we examine the influence of victim gender in death penalty cases. Furthermore, to improve our understanding of the meaning of victim gender, we consider 1 ) the joint effects of victim gender and victim race, 2 ) victimization characteristics that might explain victim gender effects, and 3) the impact of victim gender at different decision-making stages in the death penalty case process. We find that both victim gender and race are associated with death sentencing outcomes and that an examination of the joint effects of victim gender and race reveals considerable differences in the likelihood of receiving a death sentence between the most disparate victim race-gender groups. In particular, it seems that black male victim cases are set apart from all others in terms of leniency afforded to defendants. We also show that the effect of victim gender is explained largely by gender differences in the sexual nature of some homicides. An examination of prosecutorial and jury decision making reveals that although victim gender has little impact on prosecutorial decisions, it has a meaningful impact on jury decisions.
\end{abstract}

\begin{abstract}
ARTICLE
Most studies that examine extralegal disparities in capital punishment focus on the impact of defendant and/or victim race on the likelihood of receiving a death sentence (e.g., Baldus, Woodworth, and Pulaski, 1990; Baldus et al., 1998; Gross and Mauro, 1989; Paternoster et al., 2003; Pierce and Radelet, 2002). In light of the sordid history of race relations in the United States and the concerns that racial prejudice and discrimination continue to undermine the value of equality before the law in society today, it is not surprising that race figures prominently in
\end{abstract}


research on the functioning of all aspects of the criminal justice system (Ferree and Hall, 1996; Hagan, 1987).

In contrast, a paucity of research exists that emphasizes the effect of gender, especially as it relates to the victim, on sentencing outcomes in capital cases (but see Hindson, Potter, and Radelet, 2006; Holcomb, Williams, and Demuth, 2004). Indeed, many recent death penalty studies that are characterized by comprehensive data and advanced statistical procedures either marginalize victim gender in their analyses (e.g., Baldus, Woodworth, and Pulaski, 1990) or omit victim gender altogether (e.g., Baldus et al., 1998; Paternoster et al., 2003; Pierce and Radelet, 2005). ${ }^{1}$

Apparently, victim gender does not raise the constitutional concerns or social science interests that are evident in examinations of the relationship between race and the death penalty. ${ }^{2}$ This lack of interest is unfortunate. Understanding the relationship between victim gender and death penalty outcomes not only provides insight into the decision-making process of criminal justice actors and into the relevance of particular crime characteristics associated with the imposition of death sentences, but also it provokes important questions about how societal stratification and inequality —namely, the relative structural positions of victims (and offenders)—influence public perceptions of crime seriousness and official punishment responses.

Nonetheless, several recent studies do examine the role of victim gender in death penalty cases and find that defendants who murder females are more likely to receive a death sentence than defendants who murder males. However, these studies either limit their examinations to the bivariate level (e.g., Hindson, Potter, and Radelet, 2006) or have significant data shortcomings (such as limited information on case characteristics) that prevent them from reaching more confident conclusions about the relevance of victim gender in death penalty cases (e.g., Gross and Mauro, 1989; Holcomb, Williams, and Demuth, 2004; Radelet and Pierce, 1991).

In addition, several notable substantive issues exist that receive scant attention in the death penalty literature on victim gender. First, past death penalty studies on victim gender and race tend to treat victim characteristics as distinct and independent categories of interest. That is, they only examine the independent effects of gender and/or race and do not consider the potential joint effect of multiple victim statuses (see, for an exception, Holcomb, Williams, and Demuth, 2004). This point is problematic in light of a growing body of sentencing research that finds that examinations of joint effects are critical because they often reveal effects considerably larger than any single main effect and reveal extralegal disparities that are otherwise hidden when examining only additive models (e.g., LaFree, 1989; Spohn and Holleran, 2000; Steffensmeier and Demuth, 2006; Steffensmeier, Ulmer, and Kramer, 1998).

Second, explanations of the victim gender-death penalty relationship in prior studies are largely theoretical in nature. ${ }^{3}$ Because most data sets do not contain detailed information about the nature of the victimization, especially as it might relate to victim gender, explanations for the harsher treatment of defendants accused and/or convicted of murdering women (after taking into account available legal factors) usually are based on speculative or anecdotal notions of prosecutor or jury perceptions of female victims as weaker or more deserving of protection than male victims (e.g., Gross and Mauro, 1989; Hindson, Potter, and Radelet, 2006). That is, 
researchers cannot explain confidently what the victim gender effect means. For instance, it is possible that it exists simply as an artifact of uncontrolled legal factors. Alternatively, the unexplained victim gender effect may be "real" and result from differences in the perceived seriousness of crimes against women and men. Research is needed that controls more adequately for legal factors that might explain the victim gender effect and disentangles the meaning of victim gender empirically by measuring gendered concepts (e.g., female vulnerability or the sexual nature of crimes) embedded in current theoretical explanations for the harsher treatment of defendants convicted of murdering women and girls.

Third, most studies focus on death penalty outcomes and examine the factors associated with receiving a death sentence among all death-eligible cases (e.g., Hindson, Potter, and Radelet, 2006; Holcomb, Williams, and Demuth, 2004; Pierce and Radelet, 2002, 2005; Sorensen and Wallace, 1995; Williams and Holcomb, 2001). By focusing on the overall death penalty outcome and not on the various decisions that culminate in the outcome, prior studies cannot determine where in the death penalty case process-e.g., in the prosecutor's decision to seek the death penalty or in the jury's decision to impose a death sentence-victim gender matters. ${ }^{4}$

Understanding the legal contexts in which victim gender is influential improves our ability to establish the meaning of victim gender for decision makers in death penalty cases. For example, to the extent that victim gender influences the decision making of prosecutors and/or juries, we understand whether it is the legal and political discretion of legal agents or the broader social judgments of citizens that account for harsher punishments of defendants who victimize females.

This study seeks to address these gaps in the literature. We use data from one of the most frequently cited studies on racial disparities and capital punishment: the Baldus, Woodworth, and Pulaski (1990) study of Georgia's death penalty system that was a central feature of the U.S. Supreme Court case McCleskey v. Kemp (1987) and is often cited as "the most comprehensive research ever produced on sentencing disparities" in capital cases (Hindson, Potter, and Radelet, 2006: 558). The Baldus data contain detailed information about the characteristics of the defendant, victim, and crime that enable a more robust test of victim gender effects than is possible with most other available death penalty data sets. First, we examine the independent and joint effects of victim gender and race on the imposition of death sentences found in this data. Second, we explore the characteristics of the victimization and attempt to explain the harsher punishments meted out to defendants who murder women and girls. Third, we examine two key decisions in the death penalty case process (i.e., the prosecutor's decision to seek the death penalty and the jury's decision to impose the death penalty) to determine the source(s) of differential punishment. Lastly, we provide suggestions for future research and discuss the need to revisit the rich and underused Baldus data in light of our substantive and methodological findings.

\section{PRIOR RESEARCH}

Perhaps few criminal justice issues have been as closely examined as the death penalty and the factors associated with its use (for reviews, see Baldus and Woodworth, 1998; Gross and Mauro, 1989; Kleck, 1981; U.S. Government Accounting Office, 1990). A dominant theme throughout much of this research is the extent to which race, of both the defendant and the victim, influences 
court decision making and the eventual outcomes of defendants. Given the disproportionate number of black defendants in the U.S. criminal justice system and on death row as well as the historical oppression and marginalization of blacks in America, it is understandable why considerable public, legal, and scholarly attention has focused on racial equality in the application of the death penalty.

Although research indicates that the race of the defendant rarely is associated with the imposition of a death sentence (but see, Baldus et al., 1998), ${ }^{5}$ the race of the victim does seem to play a role in the outcomes of death penalty cases. Defendants who murder black victims are less likely to be sentenced to death than defendants who murder white victims (e.g., Baldus, Woodworth, and Pulaski, 1990; Keil and Vito, 1992; Paternoster et al., 2003, Pierce and Radelet, 2002; Sorensen and Wallace, 1995; Thomson, 1997; Vito and Keil, 1988; Williams and Holcomb, 2001).

One common interpretation of this phenomenon is that black victims are devalued by the court, and hence, their murderers are viewed as less deserving of a death sentence (e.g., Kleck, 1981). Similarly, jury decisions seem to be influenced by whether the victim is perceived as "worthy" of a death sentence, that is, whether their behavior contributed in some way to their victimization or whether they were an "innocent” victim (e.g., Sundby, 2003). Another explanation is that black victim cases may involve more uncertainty (Albonetti, 1987; Albonetti and Hepburn, 1996) or suffer from victim credibility concerns (Stanko, 1981) that lead prosecutors to be less likely to seek the most severe outcomes. Therefore, it is likely that black victim homicides will be underrepresented among death sentences even though such cases may meet the legal threshold for being death-eligible (see also Baumer, Messner, and Felson, 2000).

\section{EXPLAINING THE ROLE OF VICTIM GENDER}

In contrast to the considerable research on the influence of race on death penalty decisions, only a small body of research exists that considers the role of gender in capital cases (e.g., Gross and Mauro, 1989; Hindson, Potter, and Radelet, 2006; Radelet and Pierce, 1991; Williams and Holcomb, 2001). Although women (like blacks) historically have been excluded from significant aspects of economic, social, and public life in America, the legal and societal implications of the relationship between gender and death penalty outcomes are less understood. Furthermore, because men commit most death-eligible homicides, the ability to assess the relationship statistically between defendant gender and sentencing outcomes in capital cases is limited. Despite this limitation, researchers find that the gender of the victim (like the race of the victim) seems to play a role in capital cases.

Several studies find that cases with female victims are more likely to receive a death sentence than cases with male victims (e.g., Baumer, Messner, and Felson, 2000; Gross and Mauro, 1989; Radelet and Pierce, 1991; Williams and Holcomb, 2001). Unfortunately, researchers have paid less attention to explaining such results. The focal concerns perspective on legal decision making (that has focused traditionally on the influence of defendant characteristics) presented by Steffensmeier and colleagues (e.g., Steffensmeier, Ulmer, and Kramer, 1998) may provide a useful framework to understand the victim gender effect. Defendants who murder women may be perceived as more dangerous and morally blameworthy than defendants who kill men and, 
hence, more deserving of punishment (see also Baumer, Messner, and Felson, 2000). Defendants may also be viewed as creating additional hardships for families, the community, and the state. For example, killing a female victim might disrupt childcare or social support networks more than killing a male victim (see Daly, 1987, 1994).

Furthermore, female homicide victims may be perceived as engaging in less disreputable or contributing conduct associated with their own victimization compared with male victims (Baumer, Messner, and Felson, 2000; Farrell and Swigert, 1986; Sundby, 2003). Similarly, sexual assault is an aggravating factor both statutorily and de facto (as a contemporaneous felony for a felony-murder charge) in most jurisdictions (Snell, 2006). Stauffer et al. (2006) find that juries are more likely to impose death sentences in homicides involving rape. Although rare (e.g., Pierce and Radelet [2002] report that less than 2 percent of first-degree murder convictions in their 10-year Illinois sample included a contemporaneous sexual assault), perceptions about the particular heinousness of such rape-murder cases may be a contributing factor to observed victim gender effects.

\section{THE JOINT EFFECTS OF VICTIM GENDER AND RACE}

In addition to the limited amount of research that examines the impact of victim gender on death penalty case outcomes, most prior studies that examine victim gender and race in capital cases have treated victim characteristics as distinct and independent categories of interest. That is, the studies examine the main effects of gender and/or race, but they do not consider the joint effects of multiple victim characteristics in death penalty cases. Recent studies that examine the impact of defendant characteristics such as gender, race/ethnicity, and age on sentencing outcomes in noncapital cases find that, in addition to important main effects, unexpected findings emerge when the joint effects of these defendant characteristics are considered (e.g., LaFree, 1989; Spohn and Holleran, 2000; Steffensmeier and Demuth, 2006; Steffensmeier, Ulmer, and Kramer, 1998). For instance, Steffensmeier, Ulmer, and Kramer (1998) indicate that young black men in particular receive disproportionately harsher sentences than other defendant groups after accounting for important legal factors. Drawing on prior research on criminal stereotyping and their focal concerns perspective of legal decision making, they argue that young black males receive harsher punishments because they are viewed as a "dangerous class," more deserving of punishment, and less harmed by a prison term. Importantly, they call for more research to examine the joint effects of extralegal characteristics in the sentencing process.

Although contemporary death penalty research is characterized by improved samples, more detailed data on individual cases, and more rigorous statistical analyses (see Baldus and Woodworth, 1998; Zatz, 1984), even the most comprehensive analyses continue to evaluate victim race and gender as independent characteristics. Furthermore, when death penalty research has included a measure of victim gender, generally it has been only as one of numerous control variables, independent of victim race, and with little attention to the potential theoretical significance of the relationship between victim gender and case outcomes. The findings of a recent study by Holcomb, Williams, and Demuth (2004) provide support for the importance of examining the joint impact of victim characteristics. They show that the apparent independent effects of victim race and gender on death sentences in Ohio actually are a product of the strong 
association between one victim race-gender group of cases and the imposition of a death sentence. The comparison of specific race-gender victim combinations reveals that white female victim cases are the only victim race-gender combination in which the odds of receiving a death sentence are significantly different from any other reference group (i.e., white male, black female, or black male victims).

They argue that the observed "white female effect" is consistent with the historically increased concern and severe response to the victimization of white females in American culture (Holcomb, Williams, and Demuth, 2004). The perceived victimization of white females, especially by nonwhite offenders, has considerable symbolic power in the United States and has been used to support a variety of social and political goals (see, e.g., Langum, 1994; Morgan, 1978). Perhaps related to this cultural history, white females may be perceived as the group most in need of protection from violence and least likely to be responsible for their victimization. Conversely, homicides with other victim groups may affect the focal concerns of decision makers in a manner that encourages a more lenient response compared with the victimization of white females. Unlike black females and males in general, for whom violence may be perceived as a more common experience (see Hawkins, 1987; Spohn, 1994), violence against white females may represent a more serious threat because of the harm to perceived "innocent" victims - a prominent factor in capital jury decision making (Sundby, 2003).

Another possible explanation for victim gender disparity may be decision makers' perceptions of the victim's familial role and responsibilities (see Daly, 1987, 1989, 1994). Using Daly's (1987, 1989, 1994) familial justice model, Holcomb, Williams, and Demuth (2004) suggest that a victim’s status vis- `a-vis their familial roles might affect criminal justice decision making. Thus, if white females are more likely to be perceived as primary care givers, decision makers may respond to violence against them with more severity. Holcomb, Williams, and Demuth (2004: 886-7) note that, "[i]f gender and race are major determinants of status . . the white female victim is the only combination that is elevated on both characteristics. . . This could explain why homicides with black male victims receive the least severe response, i.e., they are neither white nor female.”

However, a weakness of the Holcomb, Williams, and Demuth (2004) study is the limited information available on the aggravating and mitigating circumstances in individual cases and the possible inclusion of nondeath- eligible cases in their analyses. This problem is not uncommon, as prior sentencing research (especially noncapital studies) has suffered frequently from insufficient data, which compromises the ability of researchers to account for legally relevant circumstances that affect case outcomes. The current study seeks to overcome these limitations by assessing the independent and joint effects of victim gender and race using the original data from the Baldus, Woodworth, and Pulaski (1990) study, which is noted as one of the most comprehensive and thorough examinations of the death penalty to date (e.g., Gross and Mauro, 1989). ${ }^{6}$

\section{VICTIM GENDER AND THE CONTEXTS OF DECISION MAKING}

Most prior studies do not examine where victim gender and race are 
influential in the decision-making process. For instance, are victim gender and race associated with death penalty outcomes because these characteristics influence the prosecutors responsible for seeking the death penalty, or are jurors the ones who take victim gender and race into account when deciding the seriousness of the offense and the appropriateness of a death sentence? As Baldus, Woodworth, and Pulaski (1990) and Baldus et al. (1998) note, it is critical not only to examine whether disparities exist, but also to understand at what key decision-making points any disparities are observed.

Stanko (1981) reports that prosecutorial screening decisions often include an assessment of victim attributes. Although statutory definitions limit a prosecutor's discretion to upgrade homicides to "death eligible," the discretion to downgrade death-eligible homicides can be affected by local politics, personal judgment, and internal organizational guidelines. For example, Radelet and Pierce (1985) find that victim race and gender as well as offender-victim race dyads are associated with prosecutorial decisions to upgrade or downgrade homicides from initial police reports. Paternoster (1984) finds that, in general, homicides with black victims require a higher "threshold" of aggravation than white victim cases before prosecutors seek the death penalty.

In their original study, Baldus, Woodworth, and Pulaski (1990) use current data to find that victim race plays a larger role in prosecutorial decision making than in jury decision making. However, in a later study conducted in Philadelphia, Baldus et al. (1998) find the opposite; victim race has an effect in jury decision making but not in prosecutorial decision making. Although neither of these studies examines victim gender, the findings are suggestive of a need to explore the decision-making origins of punishment disparities based on victim characteristics.

\section{DATA AND METHODS}

In the current study, we assess the impact of victim gender on the sentencing outcomes reported in the seminal Baldus, Woodworth, and Pulaski (1990) study of capital punishment in Georgia. Specifically, we use the original data from the Charging and Sentencing Study (Baldus, Woodworth, and Pulaski, 1990: 44-6). ${ }^{7}$ These data are used in the frequently cited 39-variable, core weighted, logistic regression model (Baldus, Woodworth, and Pulaski, 1990: 319, 630-1), which indicates that the odds of receiving a death sentence are 4.3 times higher in cases that involve at least one white victim than in cases that involve no white victims. ${ }^{8}$

The Charging and Sentencing Study data consist of a stratified random sample of 1,066 cases in which a defendant was indicted for murder or voluntary manslaughter and eventually was convicted in Georgia between 1973 and 1979 (Baldus, Woodworth, and Pulaski, 1990: 44-6). After weighting the cases, the sample size equals the number of cases in the population $(2,484)$ that meets these requirements during the study period. The current study replicates the original 39-variable "core model" that contains the primary findings reported by Baldus, Woodworth, and Pulaski (1990: 319-20, 630-1, Appendix L, schedule 4) and that generally is cited in the literature on racial disparities and the death penalty (e.g., Gross and Mauro, 1989; Sorensen and Wallace, 1995; Thomson, 1997). This core model includes measures of defendant race and gender as well as of victim race, but it does not include a measure of victim gender. 
The exclusion of a victim gender variable from the original core model was the result of several factors. First, the focus of the original study was to examine the impact of racial characteristics on sentencing outcomes. As such, consideration of victim gender was likely not of particular concern for the authors. Second, Baldus, Woodworth, and Pulaski (1990: 620-9, Appendix L, schedule 3) included a victim gender variable in their first set of analyses featuring the full model that included over 230 case variables, but they initially found that gender of victim was not statistically significant. The authors used stepwise regression in the full model to eliminate variables (such as victim gender) from subsequent analyses. The purpose of the core model was to isolate the most relevant statutory and aggravating factors associated with a death sentence and to determine whether the racial characteristics of the defendant or victim were statistically significant after accounting for these factors (see Kleck, 1991). It is notable, however, that several variables in the 39-variable model were found initially to be nonsignificant, but they were nonetheless retained by Baldus, Woodworth, and Pulaski (1990) in subsequent analyses.

Our contention is that gender of victim effects may be statistically significant and substantively important for our understanding of death penalty decision making, and that the probative value of retaining victim gender is considerable. Also, the original core model did not consider the joint effects of victim race and gender, as the authors were interested primarily in the independent effects of race. As a result, it is unclear, based on the core model results reported, whether victim gender is associated independently with the likelihood of receiving a death sentence in the Baldus, Woodworth, and Pulaski (1990) data or whether victim race and gender act jointly to affect death sentence outcomes. The current study examines the impact of both victim gender and victim race by including those variables in the replicated original core model. Furthermore, we explore the meaning of victim gender by looking at the contexts of sentencing - that is, the kinds of cases (sex-related vs. non-sex-related) and kinds of decisions (prosecutor vs. jury) — in which victim gender might play a meaningful role.

The current analysis has three parts. First, we replicate the original regression findings of the Baldus, Woodworth, and Pulaski (1990) study. Second, we examine the independent and joint effects of victim gender and race on the likelihood of receiving a death sentence in the replicated model. Third, we explore the meaning of victim gender by disentangling the circumstances of the victimization and by examining the relevance of victim gender at different decision-making points in death penalty cases.

\section{RESULTS}

Table 1, model 1, shows the replicated weighted logistic regression results of the original 39variable core model reported by Baldus, Woodworth, and Pulaski (1990). ${ }^{9}$ For purposes of clarity, we report only the variables of interest to the current study. ${ }^{10}$ As originally reported by Baldus, Woodworth, and Pulaski (1990), defendants who murder one or more white victims are more likely to receive a death sentence than defendants who murder nonwhite victims (odds ratio $=4.25$ ). However, the gender and race of the defendant are not related statistically to the likelihood of receiving a death sentence. 


\section{Table 1. Weighted Logistic Regression of Death Sentence Imposition on Core Variables and on Gender and Race of Victim and Defendant}

\begin{tabular}{|c|c|c|c|}
\hline Variable & $\begin{array}{l}\text { Model 1: Original } \\
\text { Baldus Model } \\
\text { [Odds ratio } \\
\text { Coefficient } \\
\text { (SE)] }\end{array}$ & $\begin{array}{l}\text { Model 2: Model 1 } \\
\text { with Single-Victim } \\
\text { Cases Only } \\
\text { [Odds ratio } \\
\text { Coefficient } \\
\text { (SE)] }\end{array}$ & $\begin{array}{c}\text { Model 3: Model } 2 \\
\text { with Female } \\
\text { Victim Added } \\
\text { [Odds ratio } \\
\text { Coefficient } \\
\text { (SE)] }\end{array}$ \\
\hline $\begin{array}{l}\text { Female victim } \\
(n=741)\end{array}$ & - & - & $\begin{array}{l}2.662^{*} \\
0.979 \\
(.398)\end{array}$ \\
\hline $\begin{array}{l}\text { White victim } \\
(n=943)\end{array}$ & $\begin{array}{l}4.252^{*+\infty} \\
1.447 \\
(.405)\end{array}$ & $\begin{array}{l}4.884^{\circ-6} \\
1.586 \\
(.433)\end{array}$ & $\begin{array}{l}5.135^{\circ * *} \\
1.636 \\
(.435)\end{array}$ \\
\hline $\begin{array}{l}\text { Female defendant } \\
(n=324)\end{array}$ & $\begin{array}{c}1.325 \\
.281 \\
(.655)\end{array}$ & $\begin{array}{c}1.607 \\
.475 \\
(.696)\end{array}$ & $\begin{array}{c}1.920 \\
.652 \\
(.683)\end{array}$ \\
\hline $\begin{array}{l}\text { Black defendant } \\
(n=1,640)\end{array}$ & $\begin{array}{c}.938 \\
-.064 \\
(.343)\end{array}$ & $\begin{array}{c}1.127 \\
.119 \\
(.367)\end{array}$ & $\begin{array}{c}1.170 \\
.157 \\
(.367)\end{array}$ \\
\hline $\begin{array}{l}\text { Weighted } \\
\text { observations }\end{array}$ & 2,484 & 2,421 & 2,421 \\
\hline
\end{tabular}

The original study included homicide incidents with multiple victims. As a result, Baldus, Woodworth, and Pulaski (1990) operationalized the victim race variable as "one or more white victims." In the current study, we limit the analysis to homicides that involve single victims in order to be certain of the gender and race of the victim. For instance, using the variables provided by Baldus, Woodworth, and Pulaski (1990), in a multiple victim case where one or more victims is white and a female victim is involved, it is unclear whether it is the female victim who is white. To resolve this complication, we delete the few multiple victim cases (63 out of 2,484 weighted cases) from the sample for the remaining analyses. ${ }^{11}$ The regression results that take into account these modifications are presented in table 1, model 2 . Limiting the sample to single-victim cases (table 1, model 2) produces results that are comparable with those obtained in the original model (table 1 , model 1 ).

Table 1, model 3, contains the results of the first reexamination of the original data with a victim gender variable added. Results indicate that the effect of victim race remains statistically significant (and actually increases slightly) after adding victim gender to the model. Homicides that involve a white victim are significantly more likely to result in a death sentence than homicides that involve a nonwhite victim after controlling for important legal factors (odds ratio = 5.13). Importantly, victim gender also has an impact on the likelihood of receiving a death sentence. The odds of receiving a death sentence are 2.66 times higher for defendants who kill a female victim than for defendants who kill a male victim. Thus, although it was excluded from the original core model by Baldus, Woodworth, and Pulaski (1990), victim gender, and not just victim race, is a significant predictor of death sentence outcomes. However, it is notable that the 
victim gender effect is smaller than the victim race effect. Next, we present the results of regression analyses that examine the joint effects of victim gender and race on death penalty outcomes.

\section{JOINT EFFECTS OF VICTIM GENDER AND RACE}

Table 2 provides the results of a weighted logistic regression analysis of death sentence imposition that includes dummy variables for each victim race-gender subgroup. All four models in table 2 are the same except the victim race-gender reference group is alternated among white female, white male, black female, and black male subgroups to allow for easy comparison. All variables that are included in table 1, model 3, are also included in table 2.

\begin{tabular}{|c|c|c|c|c|}
\hline $\begin{array}{l}\text { Race and Gender } \\
\text { of the Vietim² }\end{array}$ & $\begin{array}{c}\text { Model } 1 \\
\text { [Odds ratio } \\
\text { Coefficient } \\
\text { (SE)] }\end{array}$ & $\begin{array}{c}\text { Model } 2 \\
\text { [Odds ratio } \\
\text { Coefficient } \\
\text { (SE)] }\end{array}$ & $\begin{array}{c}\text { Model } 3 \\
\text { [Odds ratio } \\
\text { Coefficient } \\
\text { (SE)] }\end{array}$ & $\begin{array}{c}\text { Model } 4 \\
\text { [Odds ratio } \\
\text { Coefficient } \\
\text { (SE)] }\end{array}$ \\
\hline $\begin{array}{l}\text { Female victim } \\
(n=741)\end{array}$ & - & $\begin{array}{c}2.330 \\
846 \\
(442)\end{array}$ & $\begin{array}{c}3.721 \\
1.314 \\
(.635)\end{array}$ & $\begin{array}{c}14.498^{*+\infty} \\
2.674 \\
(.637)\end{array}$ \\
\hline $\begin{array}{l}\text { White victim } \\
(n=943)\end{array}$ & $\begin{array}{r}.429 \\
-.846 \\
(.442)\end{array}$ & - & $\begin{array}{c}1.597 \\
.468 \\
(.612)\end{array}$ & $\begin{array}{l}6.221^{\circ-0} \\
1.828 \\
(.529)\end{array}$ \\
\hline $\begin{array}{l}\text { Female defendant } \\
(n=324)\end{array}$ & $\begin{array}{r}.269^{*} \\
-1.314 \\
(.635)\end{array}$ & $\begin{array}{c}.626 \\
-.468 \\
(.612)\end{array}$ & - & $\begin{array}{l}3.896^{*} \\
1.360 \\
(.683)\end{array}$ \\
\hline $\begin{array}{l}\text { Black defendant } \\
(n=1,640)\end{array}$ & $\begin{array}{c}.069 * * \\
-2.674 \\
(.637)\end{array}$ & $\begin{array}{c}.161^{* 0-} \\
-1.828 \\
(.529)\end{array}$ & $\begin{array}{c}.257^{*} \\
-1.360 \\
(.683)\end{array}$ & - \\
\hline $\begin{array}{l}\text { Weighted } \\
\text { observations }\end{array}$ & 2,421 & 2,421 & 2,421 & 2,421 \\
\hline
\end{tabular}

${ }^{*} p<.05 ;{ }^{* *} p<.01:{ }^{* * *} p<.001$.

"Sample sizes listed under "Rase and Gender of the Vistim" are weighted observatione.

Three notable findings emerge from our analysis of joint effects. First, considerable differences exist in the likelihood of receiving a death sentence between the most disparate victim racegender groups. Even after controlling for the variables that Baldus, Woodworth, and Pulaski (1990) identify as most closely associated with a death sentence, the results reported in model 4 show that the odds of receiving a death sentence for killing a white female are about 14.5 times higher than the odds of receiving a death sentence for killing a black male. White male-black male (odds ratio $=6.22$ ) and black female-black male (odds ratio $=3.90$ ) victim differences are also statistically significant but somewhat smaller. Although this finding is consistent with earlier research reporting a zeroorder hierarchy of death sentencing patterns based on victim 
characteristics, with black male victim and white female victim cases having the lowest and highest proportion of death sentences, respectively (e.g., Paternoster, 1984; Radelet and Pierce, 1991; Williams and Holcomb, 2001), evidence of such a pattern even after controlling for numerous legally relevant factors is noteworthy.

Second, compared with cases that involve white female, white male, and black female victims, cases with black male victims on average are less likely to result in the imposition of a death sentence. That is, no matter the comparison group, defendants who kill black male victims, even after controlling for numerous important legal and extralegal factors, are less likely to receive the death penalty. This finding is notable in that it seems to set black male victim cases apart from all others in terms of leniency afforded to their killers. In contrast, the likelihood of receiving a death sentence is not statistically different for cases that involve white male victims versus white female victims. Also, the outcomes of cases that involve white male victims and black female victims are not statistically different.

Third, the findings in the current study show both similarities and differences with the findings of Holcomb, Williams, and Demuth's (2004) study of death sentence outcomes in Ohio. The findings are similar in that they both report that white female victim cases and black male victim cases represent the most disparate groups in terms of sentencing outcomes. Statistically, cases with a white female victim are treated most harshly and cases with a black male victim are treated least harshly. However, the findings are dissimilar because Holcomb, Williams, and Demuth (2004) show that cases with white female victims are singularly different from all other cases. In the current study, it is black male victim cases that seem to stand out.

\section{THE SEXUALIZED CONTEXT OF FEMALE VICTIMIZATION}

Although prior studies that report a victim gender effect on death penalty outcomes often speculate about the meaning of such findings (e.g., Gross and Mauro, 1989; Holcomb, Williams, and Demuth, 2004), these explanations remain speculative in nature because the data often lack the detailed victim and case information required to disentangle empirically the meaning of the victim gender effect. Luckily, the Baldus data contain numerous variables that document the characteristics of the victimization event and enable us to explore why defendants who victimize females are punished more harshly than defendants who victimize males. ${ }^{12}$ To assess which characteristics of the victimization event help to explain the victim gender effect, we introduce each victimization variable individually into the final regression model presented in table 1 (results available on request). To the extent that the addition of a variable to the model greatly reduces the size of the victim gender effect, this finding is empirical evidence that the victimization characteristic plays a role in differentiating the sentencing outcomes received by defendants in cases that involve female and male victims. For victimization variables that already are included in the model [i.e., they are part of the 39-variable core model developed by Baldus, Woodworth, and Pulaski (1990)], we assess their impact by examining the size of the victim gender effect in models that include and exclude the individual variables.

Our examination reveals only three victimization factors (all measured dichotomously) that greatly or fully reduce the size of the victim gender effect discussed earlier: rape, forcing the 
victim to disrobe, and killing an unclothed victim. Notably, no other victimization factor reduces the effect of victim gender on the likelihood of receiving a death sentence (results not shown). The results of the analysis that show the impact of the three influential victimization factors are presented in table 3 . All models presented in table 3 include (but do not show) the variables in the analysis presented in table 1 . Also, the effect of victim race remains statistically significant and relatively unchanged (odds ratios between 4.8 and 5.5) across the models in table 3.

Table 3, model 1, represents a "baseline" model in which the rape variable is removed. The size of the victim gender effect (odds ratio $=3.43$ ) is statistically significant and larger than the victim gender effect that was presented earlier in table 1 , which controlled for rape (odds ratio = 2.66). The table 1 , model 3 , findings are presented again in table 3 , model 2 . In

\section{Table 3. Gender and Race of Victim Effects on Death Sentence Imposition Before and After Controlling for Sex-Related Victimization Variables}

\begin{tabular}{|c|c|c|c|c|c|}
\hline Variable & $\begin{array}{l}\text { Medel } 1^{2} \\
\text { [Odds ratie } \\
\text { Coefficient } \\
\text { (SE)] }\end{array}$ & $\begin{array}{l}\text { Model } 2 \\
\text { [Odds ratio } \\
\text { CoefGient } \\
\text { (SE)] }\end{array}$ & $\begin{array}{l}\text { Model } 3 \\
\text { [Odds ratio } \\
\text { Coefficient } \\
\text { (SE)] }\end{array}$ & $\begin{array}{c}\text { Medel } 4 \\
\text { [Odds ratio } \\
\text { Ceeffidient } \\
\text { (SE)] }\end{array}$ & $\begin{array}{l}\text { Model } 5 \\
\text { [Odds ratie } \\
\text { Coefficient } \\
\text { (SE)] }\end{array}$ \\
\hline Female victim & $\begin{array}{l}3.428^{6+4} \\
1.232 \\
(.370)\end{array}$ & $\begin{array}{l}2.662^{*} \\
.979 \\
(.398)\end{array}$ & $\begin{array}{c}2.113 \\
.748 \\
(.409)\end{array}$ & $\begin{array}{c}1.784 \\
.579 \\
(.431)\end{array}$ & $\begin{array}{c}1.669 \\
512 \\
(.443)\end{array}$ \\
\hline White victim & $\begin{array}{l}5.507^{* * 6} \\
1.706 \\
(.432)\end{array}$ & $\begin{array}{l}5.135^{* 4 *} \\
1.636 \\
(.435)\end{array}$ & $\begin{array}{l}5.217^{* 4 *} \\
1.652 \\
(.443)\end{array}$ & $\begin{array}{l}5.038^{* * 4} \\
1.617 \\
(.447)\end{array}$ & $\begin{array}{l}4.802^{4 * 4} \\
1.569 \\
(.448)\end{array}$ \\
\hline Rape involved & - & $\begin{array}{l}6.341^{*} \\
1.847 \\
(.805)\end{array}$ & - & - & - \\
\hline $\begin{array}{l}\text { Victim vithout } \\
\text { clothes when } \\
\text { killed }\end{array}$ & - & - & $\begin{array}{l}6.430^{6.4} \\
1.861 \\
(513)\end{array}$ & - & - \\
\hline $\begin{array}{l}\text { Victim forced to } \\
\text { disrobe }\end{array}$ & - & - & - & $\begin{array}{l}9.007^{* 46} \\
2.198 \\
(.544)\end{array}$ & - \\
\hline $\begin{array}{l}\text { Sex-related } \\
\text { victimization } \\
\text { scale (sum of } \\
\text { measures) }\end{array}$ & - & - & - & - & $\begin{array}{l}2.691^{* * *} \\
.990 \\
(.246)\end{array}$ \\
\hline $\begin{array}{l}\text { Weighted } \\
\text { observations }\end{array}$ & 2,421 & 2,421 & 2,421 & 2,421 & 2,421 \\
\hline
\end{tabular}

${ }^{*} p<.05 ;{ }^{*+} p<.01:{ }^{*+*} p<.001$.

"Models ibclude all variables included in table 1 analysis

table 3, model 3, after controlling for those cases in which the victim was without clothes when killed, the effect of victim gender is reduced to statistical nonsignificance (odds ratio $=2.11$ ). Similarly, controlling for whether the victim was forced to disrobe (table 3, model 4) also reduces the effect of victim gender to statistical nonsignificance (odds ratio $=1.78$ ). Table 3 , model 5, shows the effect of victim gender after controlling for a scale measure of sex-related victimization (odds ratio $=1.67$, n.s.). This scale (which is used in the remaining analyses to 
measure sex-related victimization) represents the sum of the three influential victimization measures and ranges from 0 to 3 . Three main findings emerge from the results presented in table 3. First, it is notable the large number of victim and victimization factors that do not explain the victim gender gap in punishment. For instance, we find that victim gender differences in the likelihood of receiving a death sentence are not explained by such factors as the helplessness or defenselessness of the victim, the size difference between the victim and defendant, the method of killing, or the relationship between the victim and the defendant.

Second, we find that the harsher sentences received by defendants who victimize females rather than males are explained by differences in the circumstances of female and male victimizations. After accounting for the greater likelihood of sex-related victimization among female victims, no victim gender differences exist in death penalty outcomes.

Third, it seems that cases involving sex-related victimization are more likely to result in a death sentence. This finding is understandable because rape is allowable as an aggravating factor in death-eligible cases. However, in the current study, it is not rape victimization that best explains the victim gender effect. Indeed, even after controlling for rape, victim gender remains significantly predictive of receiving a death sentence. Rather, it is the forced nudity of the victim that fully explains the harsher sentences received by defendants who kill females vis-` a-vis males. This finding suggests that prosecutors or jurors may view the sexual degradation or humiliation of the victim, and not just forced sex, as particularly heinous and deserving of the death penalty. In the next section of the analysis, we explore this issue by examining the impact of victim gender at two different stages in the death penalty case process. ${ }^{13}$

\section{VICTIM GENDER AT TWO STAGES IN THE DEATH PENALTY CASE PROCESS}

Prior studies that have examined victim gender and the death penalty have tended to focus on the overall outcome of the case process (i.e., whether victim gender is related to ultimately receiving a death sentence). But focusing on the correlates of the final outcome ignores the varying influence that victim gender may have in the decision making of legal agents and jurors at different stages of the case process. In the current study, we examine two important decisionmaking stages in the larger case process: 1 ) the prosecutorial decision to seek the death penalty after a murder conviction and 2) the jury decision to impose the death penalty during the penalty phase of the trial. To better tease out where victim gender effects are manifested in the case process, we present regression results for victim gender and race (controlling for the core variables used in earlier analyses) both before and after taking into account sex-related victimization.

Table 4 reports the effects of victim gender and race on the overall imposition of the death penalty (model 1), the prosecutor's decision to seek the death penalty (model 2), and the jury's decision to impose the death penalty (model 3) before controlling for sex-related victimization. As such, the control for rape is not included in these models and serves as a comparison for the stage-specific, decision-making findings presented in models 2 and 3. 


\section{Table 4. Gender and Race of Victim Effects at Two Stages in the Death Penalty Case Process}

\begin{tabular}{|c|c|c|c|}
\hline \multirow[t]{2}{*}{ Variable } & $\begin{array}{c}\text { Model 1: DP } \\
\text { Imposed Among all } \\
\text { Cases }\end{array}$ & $\begin{array}{c}\text { Model 2: DP } \\
\text { Sought by } \\
\text { Prosecutor After } \\
\text { Murder Conviction }\end{array}$ & $\begin{array}{c}\text { Model 3 DP } \\
\text { Imposed by Jury at } \\
\text { Penalty Trial }\end{array}$ \\
\hline & $\begin{array}{l}\text { [Odds ratio } \\
\text { Coefficient } \\
\text { (SE)] }\end{array}$ & $\begin{array}{l}\text { [Odds ratio } \\
\text { Coefficient } \\
\text { (SE)] }\end{array}$ & $\begin{array}{c}\text { [Odds ratio } \\
\text { Coeffieient } \\
\text { (SE)] }\end{array}$ \\
\hline Female victim & $\begin{array}{l}3.428^{* * *} \\
1.232 \\
(.370)\end{array}$ & $\begin{array}{c}1.055 \\
.054 \\
(.323)\end{array}$ & $\begin{array}{l}7.614^{* *} \\
2.030 \\
(.700)\end{array}$ \\
\hline White victim & $\begin{array}{l}5.507^{* * *} \\
1.706 \\
(.432)\end{array}$ & $\begin{array}{l}4.407^{* * *} \\
1.549 \\
(.351)\end{array}$ & $\begin{array}{l}3059 \\
1.118 \\
(.640) \\
\end{array}$ \\
\hline $\begin{array}{l}\text { Weighted } \\
\text { observations }\end{array}$ & 2,421 & 663 & 215 \\
\hline
\end{tabular}

In table 4 , model 1 , both victim gender (odds ratio $=3.43$ ) and victim race (odds ratio $=5.51$ ) are statistically related to receiving a death sentence. Examining table 4, model 2, victim gender has no effect on prosecutors' decisions to seek the death penalty after a murder conviction (odds ratio $=1.06$, n.s.). In contrast, victim race has a statistically significant effect on prosecutors' decisions to seek the death penalty. The odds of seeking the death penalty after a murder conviction are 4.4 times greater in cases that involve white victims than in cases that involve black victims. In table 4 , model 3 , the victim gender and victim race results are reversed. Juries are significantly more likely to impose the death penalty in cases that involve a female victim than a male victim (odds ratio $=7.61$ ). But no statistically significant difference exists in the likelihood of receiving a death sentence from a jury based on the race of the victim (odds ratio $=$ 3.06, n.s.), although it should be noted that the size of the sample in table 4, model 3 , is small.

In sum, if we only examined the final outcome of the death penalty process, we would miss differences in the impact of victim gender and victim race at different stages of the decisionmaking process. Notably, victim gender matters for juries but not for prosecutors. In contrast, victim race influences prosecutors' decisions more than juries' decisions. ${ }^{14}$

An additional analysis was conducted (not reported here) to determine whether sex-related victimization variables explained the female victim effect at the jury decision-making stage. In effect, we replicated the analyses in table 3 , model 5 , for the jury decision-making stage found in table 4, model 3. Results indicated that the female victim effect diminished at the jury decisionmaking stage after including the sex-related victimization variables. In fact, the female victim effect found for juries in table 4, model 3 , was no longer statistically significant when sex-related victimization variables were included. Although a large odds ratio remained (odds ratio $=3.995$ ), the statistical nonsignificance of the female victim variable could be a function of the smaller sample size in these analyses. Nonetheless, the substantive significance of this finding suggests that, although sex-related victimization is an important consideration, victim gender remains an 
important consideration. Future research should include larger sample sizes to determine more definitively whether the female victim effect remains when sex-related victimization variables are included.

\section{DISCUSSION}

Although the seminal importance of the Baldus, Woodworth, and Pulaski (1990) study as an investigation of the influence of race on death penalty outcomes and its legal implications is certain, it is also clear that much can be learned by revisiting the data. In an early review of the study, Kleck (1991) notes perceptively that, whereas the data are impressive, from a social science perspective, much exists in the study for scholars to reexamine. Because the study is focused so narrowly on issues of race significant to the litigation in McCleskey v. Kemp (1987), many explanatory and methodological issues are left unexplored. To our knowledge, the only published study that uses the Baldus, Woodworth, and Pulaski (1990) data is Beck and Shumsky's (1997) study that reports that cases with appointed counsel are more likely to result in a death sentence than those with privately retained counsel.15 Various reasons may exist for this, but contributing factors likely include the size of the data set and the complexity of the analyses as well as the presentation of the findings within the original text. With so many footnotes and appendices, even the most dedicated readers can become quickly overwhelmed (see Kleck, 1991).

Using the Baldus, Woodworth, and Pulaski (1990) data, the current study responds to Holcomb, Williams, and Demuth's (2004) challenge for researchers to consider the potential joint effects of victim race and gender on death penalty outcomes as well as contributes to a growing body of research that notes the importance of exploring the impact of multiple defendant and victim statuses on sentencing outcomes (e.g., Steffensmeier, Ulmer, and Kramer, 1998). We find that, in addition to victim race, victim gender is also an important predictor of death sentence outcomes. Defendants who murder females are more likely to receive a death sentence than defendants who murder males. Furthermore, we show that large differences exist in the likelihood of receiving a death sentence when the variables "victim race" and "victim gender" are considered jointly. Cases that involve white female victims are treated the most harshly, and cases that involve black male victims are treated the most leniently. Importantly, it seems that the outcomes of black male victim cases are the most divergent; fewer differences exist among the other three victim racegender case types.

The empirical finding and theoretical explanation of the "black male victim effect" in the current study is consistent with the findings/explanations of prior studies that examine the joint impact of multiple defendant characteristics on noncapital sentencing outcomes (e.g., Demuth and Steffensmeier, 2004; Steffensmeier, Ulmer, and Kramer, 1998). Guided by the focal concerns perspective of decision making developed by Steffensmeier and colleagues, these past studies argue that black male defendants receive disproportionately harsher sentences than other defendants, in part because black men are viewed with more suspicion and are perceived as less harmed by prison. Similarly, less sympathy may exist for black male victims vis- `a-vis other victims perhaps because they are viewed as more responsible for their victimization. As a result, defendants who murder black males are the least likely to receive a death sentence. 
Additionally, our findings provide support for the importance of sexrelated victimization with regard to imposition of a death sentence. When sex-related variables were controlled, much of the observed female effect diminished, which suggests that the sexual nature of female victimization, in particular the degradation and humiliation of the victim, is the key to understanding the female victim effect. On a related note, whereas victim race effects were the result of prosecutorial decision making, the observed victim gender effects were the result of jury decision making. Baumer, Woodworth, and Pulaski (2000) report a similar set of findings; in effect, different victim characteristics seem to matter at different decision-making points. It may very well be that the sexually degrading nature of some female victimizations evokes strong sympathy from jury members, but as mentioned, this can only be inferred because of the small number of cases.

These findings are slightly different from those reported by Holcomb, Williams, and Demuth (2004), which found that white female victim cases stand apart from the others. This finding is important theoretically because instead of suggesting a symbolic protection of white women, the findings are consistent with the notion that black male victims are devalued in the adjudication process. It is also possible that the different findings reported in Holcomb, Williams, and Demuth (2004) and the current study are a function of the social-political-cultural context in which those cases were decided. The Holcomb, Williams, and Demuth (2004) study was conducted with data collected in Ohio during the 1990s, although the Baldus data used in the current study were collected from Georgia during the 1970s. Prior research has demonstrated how the specific context of sentencing practices can affect aggregate-based research outcomes (see, for example, Dixon, 1995; Myers and Talarico, 1986). The differences in outcomes may be simply a reflection of different attitudes and concerns of decision makers at different times and cultural contexts. It only strengthens the need for continuing research that uses the quality of data and the analyses reported here.

We are hopeful that the current study will stimulate additional research using the Baldus data. It is noteworthy that for nearly two decades scholars have accepted the validity of the data and findings of the Baldus, Woodworth, and Pulaski (1990) study, but so few actually have explored the data and examined questions that can be addressed with the data. For instance, Kleck (1991) notes that Baldus, Woodworth, and Pulaski (1990) devote considerable attention to constructing different statistical models to ensure the robustness of the victim race effect, but they spend less time actually explaining why the victim's race continues to affect sentencing decisions postFurman v. Georgia (1972). Similarly, additional research is needed to explore the particular case circumstances that account for the differential treatment of defendants based on the gender of their victim. That is, why do female victim cases lead to harsher outcomes for defendants? Is it their perceived vulnerability, their child care responsibilities, the sexual nature of their victimizations, or something else altogether? This research is particularly important for theory development in the sentencing literature, considering that many contemporary data sources lack the kind of detail and richness provided by the Baldus, Woodworth, and Pulaski (1990) study. 


\section{REFERENCES}

Albonetti, Celesta. 1987. Prosecutorial discretion: The effects of uncertainty. Law \& Society Review 21:291-313.

Albonetti, Celesta, and John Hepburn. 1996. Prosecutorial discretion to defer criminalization: The effects of defendant's ascribed and achieved status characteristics. Journal of Quantitative Criminology 12:63-81.

Baldus, David, and George Woodworth. 1998. Race discrimination and the death penalty: An empirical and legal overview. In America's Experiment with Capital Punishment, eds. James Acker, Robert Bohm, and Charles Lanier. Durham: Carolina Academic Press.

Baldus, David, George Woodworth, and Charles Pulaski. 1990. Equal Justice and the Death Penalty: A Legal and Empirical Analysis. Boston, MA: Northeastern University Press.

Baldus, David, George Woodworth, Catherine Grosso, and Aaron Christ. 2002. Arbitrariness and discrimination in the administration of the death penalty: A legal and empirical analysis of the Nebraska experience (1973-1999). Nebraska Law Review 88:486-753.

Baldus, David, George Woodworth, David Zuckerman, Neil Alan Weiner, and Barbara Broffitt. 1998. Racial discrimination and the death penalty in the post-Furman era: An empirical and legal overview, with recent findings from Philadelphia. Cornell Law Review 83:1638-770.

Baumer, Eric, Steven Messner, and Richard Felson. 2000. The role of victim characteristics in the disposition of murder cases. Justice Quarterly 17:281-307.

Beck, James, and Robert Shumsky. 1997. A comparison of retained and appointed counsel in cases of capital murder. Law and Human Behavior 21:525-38.

Chiricos, Theodore, and Charles Crawford. 1995. Race and imprisonment: A contextual assessment of the evidence. In Ethnicity, Race, and Crime, ed. Darnell Hawkins. Albany: State University of New York Press.

Daly, Kathleen. 1987. Structure and practice of familial-based justice in a criminal court. Law \& Society Review 21:265-90.

Daly, Kathleen. 1989. Neither conflict nor labeling nor paternalism will suffice: Intersections of race, ethnicity, gender, and family in criminal 
justice decisions. Crime and Delinquency 35:136-68.

Daly, Kathleen. 1994. Gender, Crime, and Punishment. New Haven, CT: Yale University Press.

Demuth, Stephen. 2003. Racial and ethnic differences in pretrial release decisions and outcomes: A comparison of Hispanic, black, and white felony arrestees. Criminology 41:873-908.

Demuth, Stephen, and Darrell Steffensmeier. 2004. The impact of gender and race-ethnicity in the pretrial release process. Social Problems 51:222-42.

Dixon, Jo. 1995. The organizational context of criminal sentencing. American Journal of Sociology 5:1157-98.

Farrell, Ronald, and Victoria Swigert. 1986. Adjudication in homicide: An interpretive analysis of the effects of defendant and victim social characteristics. Journal of Research in Crime and Delinquency 23:349-69.

Ferree, Myra, and Elaine Hall. 1996. Gender, race, and class in mainstream textbooks. American Sociological Review 61:929-50.

Furman v. Georgia. 1972. 408 U.S. 238.

Gross, Samuel, and Robert Mauro. 1989. Death and Discrimination: Racial Disparities in Capital Sentencing. Boston, MA: Northeastern University Press.

Hagan, John. 1987. Review essay: A great truth in the study of crime. Criminology 25:421-8.

Hawkins, Darnell. 1987. Beyond anomalies: Rethinking the conflict perspective on race and criminal punishment. Social Forces 65:719-45.

Hindson, Stephanie, Hillary Potter, and Michael Radelet. 2006. Race, gender, region, and death sentencing in Colorado, 1980-1999. Colorado Law Review 77:549-74.

Holcomb, Jefferson, Marian Williams, and Stephen Demuth. 2004. White female victims and death penalty research. Justice Quarterly 21:877-902.

Kalven, Harry, and Hans Zeisel. 1966. The American Jury. Boston, MA: Little, Brown. 
Keil, Thomas, and Gennaro Vito. 1992. The effects of the Furman and Gregg decisions on black-white execution ratios in the South. Journal of Criminal Justice 20:217-26.

Kleck, Gary. 1981. Racial discrimination in criminal sentencing: A critical evaluation of the evidence with additional evidence on the death penalty. American Sociological Review 46:783-805.

Kleck, Gary. 1991. Review of Equal Justice and the Death Penalty: A Legal and Empirical Analysis, by David C. Baldus, George Woodworth, and Charles A. Pulaski, Jr. Contemporary Sociology 20:598-9.

LaFree, Gary. 1989. Rape and Criminal Justice. Belmont, CA: Wadsworth.

Langum, David. 1994. Crossing Over the Line: Legislating Morality and the Mann Act. Chicago, IL: University of Chicago Press.

McCleskey v. Kemp. 1987. 481 U.S. S. Ct. 279.

Morgan, Patricia. 1978. The legislation of drug law: Economic crisis and social control. Journal of Drug Issues 8:53-62.

Myers, Martha, and Susette Talarico. 1986. The social contexts of racial discrimination in sentencing. Social Problems 33:236-51.

Paternoster, Raymond. 1984. Prosecutorial discretion in requesting the death penalty: A case of victim-based racial discrimination. Law \& Society Review 18:437-78.

Paternoster, Raymond, Robert Brame, Sarah Bacon, Andrew Ditchfield, David Bierie, Karen Beckman, et al. 2003. An Empirical Analysis of Maryland's Death Sentencing System with Respect to the Influence of Race and Legal Jurisdiction: Final Report. http://www.newsdesk.umd. edu/pdf/finalrep.pdf.

Pierce, Glenn, and Michael Radelet. 2002. Race, region, and death sentencing in Illinois, 1988-1997. Oregon Law Review 81:39-96.

Pierce, Glenn, and Michael Radelet. 2005. The impact of legally inappropriate factors on death sentencing for California homicides, 1990-1999.

Santa Clara Law Review 46:41-6.

Radelet, Michael, and Glenn Pierce. 1985. Race and prosecutorial discretion in homicide cases. Law \& Society Review 19:587-621.

Radelet, Michael, and Glenn Pierce. 1991. Choosing who will die: Race 
and the death penalty in Florida. Florida Law Review 43:1-34.

Snell, Tracy. 2006. Capital Punishment, 2005. Washington, DC: Department of Justice, Bureau of Justice Statistics.

Sorensen, Jonathan, and Donald Wallace. 1995. Capital punishment in Missouri: Examining the issues of racial disparity. Behavioral Sciences and the Law 13:61-80.

Spears, Jeffrey, and Cassia Spohn. 1997. The effect of evidence factors and victim characteristics on prosecutors' charging decisions in sexual assault cases. Justice Quarterly 14:501-24.

Spohn, Cassia. 1994. Crime and the social control of blacks: Offender/victim race and the sentencing of violent offenders. In Inequality, Crime, and Social Control, eds. George Bridges and Martha Myers. Boulder, CO: Westview.

Spohn, Cassia, and David Holleran. 2000. The imprisonment penalty paid by young, unemployed, Black, and Hispanic male offenders. Criminology 38:281-306.

Stanko, Elizabeth. 1981. The impact of victim assessment on prosecutors' screening decisions: The case of the New York County district attorney's office. Law \& Society Review 16:225-39.

Stauffer, Amy, Dwayne Smith, John Cochran, Sondra Fogel, and Beth Bjerregaard. 2006. The interaction between victim race and gender on sentencing outcomes in capital murder trials: A further exploration. Homicide Studies 10:98-117.

Steffensmeier, Darrell, and Stephen Demuth. 2006. Does gender modify the effects of race-ethnicity on criminal sanctioning? Sentences for male and female white, black, and Hispanic defendants. Journal of Quantitative Criminology 22:241-61.

Steffensmeier, Darrell, Jeffrey Ulmer, and John Kramer. 1998. The interaction of race, gender, and age in criminal sentencing: The punishment cost of being young, black, and male. Criminology 36:763-98.

Sundby, Scott. 2003. The capital jury and empathy: The problem of worthy and unworthy victims. Cornell Law Review 88:343-81.

Thomson, Ernie. 1997. Discrimination and the death penalty in Arizona. Criminal Justice Review 22:65-76. 
U.S. Government Accounting Office. 1990. Death Penalty Sentencing Research Indicates Pattern of Racial Disparities. Washington, DC: U.S. Government Accounting Office.

Vito, Gennaro, and Thomas Keil. 1988. Capital sentencing in Kentucky: An analysis of the factors influencing decision making int eh postGregg period. Journal of Criminal Law and Criminology 79:483-502.

Williams, Marian, and Jefferson Holcomb. 2001. Racial disparity and death sentences in Ohio. Journal of Criminal Justice 29:207-18.

Zatz, Marjorie. 1984. Race, ethnicity, and determinate sentencing: A new dimension to an old controversy. Criminology 22:147-71.

\section{NOTES}

* Core support was provided by the Crime and Justice Research Lab and the Center for Family and Demographic Research at Bowling Green State University. Direct correspondence to Marian R. Williams, Criminal Justice Program, 223 Health Center, Bowling Green State University, Bowling Green, OH 43403 (e-mail: marian@bgnet.bgsu.edu).

1. See Williams and Holcomb (2001) and Holcomb, Williams, and Demuth (2004) for a more thorough critique of the prior research on victim gender and death penalty research.

2. A body of research exists that examines the role of both defendant and victim gender in noncapital cases (e.g., Baumer, Messner, and Felson, 2000; Farrell and Swigert, 1986), but its findings are not well integrated into the death penalty literature (see, for exceptions, Holcomb, Williams, and Demuth, 2004; Williams and Holcomb, 2001).

3. A reliance on theoretical explanations for gender and race effects is a limitation of sentencing research in general. Most sentencing data are collected by government agencies primarily for administrative purposes and do not provide much of the detailed case, defendant, and victim information preferred for robust empirical tests of social science research questions pertaining to gender and race.

4. See Demuth (2003) for a discussion about the importance of distinguishing between decisions and outcomes in criminal case process research. 
5. This result is in contrast to the findings of prior research on the relationship between race and sentencing in noncapital cases that show that black defendants are more likely to be sentenced to jail or to prison than white defendants at conviction, net of legal controls (for review, see Chiricos and Crawford, 1995). One possible explanation for the differences in capital and noncapital cases, which is consistent with the liberation hypothesis (Baumer, Messner, and Felson, 2000; Kalven and Zeisel, 1966; Spears and Spohn, 1997), is that the perceived seriousness of the offense in capital cases reduces the willingness of decision makers to exercise broad discretion compared with noncapital cases, thus reducing the possible influence of defendants' race. Another possible explanation is methodological. Significant race findings in noncapital sentencing studies may be an artifact of model misspecification. Detailed case characteristics that are often included in death penalty analyses (e.g., victim characteristics or aggravating factors) are often not available in the data sets used in many noncapital sentencing studies. The inclusion of these factors could reduce the effect of defendants' race on sentencing outcomes.

6. Baldus and his colleagues have conducted similar analyses since the original Georgia study in a variety of jurisdictions, including Nebraska (Baldus et al., 2002) and Philadelphia (Baldus et al., 1998). Furthermore, comprehensive studies have been conducted in Maryland (Paternoster et al., 2003) and Illinois (Radelet and Pierce, 2002). However, to our knowledge, the Baldus, Woodworth, and Pulaski (1990) study is the only one with publicly available data. Furthermore, it is still considered by many to be the definitive study to date on the relationship between race and the death penalty.

7. The Baldus, Woodworth, and Pulaski (1990) study data are publicly available through the Inter-University Consortium for Political and Social Research website (www.icpsr.umich.edu).

8. The original 39-variable core model was also the focus of McCleskey v. Kemp (1987).

9. The weighted logistic regression results presented by Baldus, Woodworth, and Pulaski (1990: 630) are replicated exactly using the GENMOD procedure with binomial distribution in SAS. The cases in the model are weighted using the variable "casewgt" provided in the data set.

10. The variables in the original 39-variable core model are included in all models reported in all tables (unless otherwise noted). The following variables constitute the 39-variable core model: defendant was black; one or more white victims; armed robbery involved; motive to avenge role by judicial officer, DA, lawyer; family, lover, liquor, barroom quarrel; one or more coperpetrators involved; coperpetrator received a lesser sentence; defendant admits guilt and no defense asserted; defendant prime mover in planning of homicide or contemporaneous offense; history of drug or alcohol abuse; victim was drowned; defendant was 
female; hate motive; defendant motive to collect insurance; jealousy motive; kidnapping involved; prior record of murder, armed robbery, rape, or kidnapping; defendant caused death risk in public place to two or more people; murder for money/value for self/other; murder for hire; victim was police/corrections/fireman on duty; defendant was prisoner or escapee; killed to avoid, stop arrest of self, other; rape/armed robbery/kidnapping involving silenced victim/execution/ victim pleaded; mental torture; defendant retired, student, juvenile, housekeeper; multiple gunshots; multiple stabbing; number of prior murder convictions for defendant; defendant not triggerman; non-property-related contemporaneous crime; number of defendant felony prison terms; rape involved; defendant under 17 years of age; victim was stranger; victim was tortured physically; defendant killed two or more people; victim was bedridden/handicapped; victim was 12 or younger; one or more convictions for VPC/burglary/arson; and victim was weak or frail.

11. As a result of deleting multiple-victim cases from the sample, two variables are removed from the regression models used in the current study vis-`a-vis the original Baldus model: "twovic" and "avenge." The variable "twovic" is removed because no cases are included in the model that involve two or more victims. The variable "avenge" is removed because the deletion of multiple-victim cases results in insufficient variation in the variable to produce a stable regression estimate.

12. We examine the following victimization variables: torture/depravity; sexual perversion; victim was a hostage; victim offered no provocation; victim killed with poison; victim was pregnant, disabled, or helpless; victim was 12 years old or younger; victim was a witness; victim was part of a lover's triangle; victim and defendant had history of bad blood; victim verbally abused defendant earlier; victim verbally abused friend of defendant; victim provoked defendant by abusing person defendant cared for; victim accused defendant of misconduct; victim asleep or just awakened; victim assaulted defendant; victim assaulted person defendant cared about; victim assaulted defendant earlier; victim assaulted person defendant cared for; victim bedridden/handicapped; victim was a coperpetrator; victim defenseless because of youth; victim defenseless because of advanced age; victim verbally provoked defendant; victim physically injured defendant earlier; victim prior injured person defendant cared for; victim physically injured defendant; victim injured person defendant cared about; victim defenseless because of size difference or number of defendants; victim threatened defendant earlier; victim threatened person defendant cared about; victim verbally threatened defendant; victim verbally threatened person defendant cared for; victim weak or frail; victim a stranger; malice/victim defenseless; malice/no victim provocation; victim was drowned; victim killed with gun; victim without clothes when killed; victim experienced a slow death; victim strangled; victim was armed; victim was a family friend or intimate; victim bound and gagged; victim forced to disrobe; sexual perversion other than rape; slashed throat of victim; victim pleaded for life; victim killed in presence of family or 
close friends; rape involved; and victim was tortured physically.

13. Consistent with our interest in examining the joint effects of victim race and gender, we included the "sex-related victimization" variable in models with the victim gender-race subgroups. Results (not shown) are consistent with those reported in table 3 and indicate that after controlling for sex-related victimization, the effect of victim gender is reduced to statistical nonsignificance similarly in cases that involve white and black victims (i.e., a victim race [but no victim gender] effect remains). However, it is notable that after controlling for sex related victimization, the difference between the likelihood of white female and black female victim cases resulting in a death sentence (reported in table 2, model 1) is also reduced to statistical nonsignificance. This result suggests that observed racial differences in death sentencing rates for female victim cases may partially be caused by different sexual victimization rates for white females compared with black females.

14. Unfortunately, sample size limitations made additional analyses of the data at different decision-making stages difficult. Too few cases were available to replicate earlier models at different stages with the four victim race-gender subgroups (see footnote 12).

15. A reviewer of an earlier draft of this manuscript also pointed out that Beck and Shumsky (1997) actually used the Procedural Reform Study data, not the larger Capital Charging and Sentencing data that are used in the current study, and that served as the primary source of data used in the McCleskey case. 